\title{
A Proposed Sustainable Model of Food Systems:
}

\author{
Social and Environmental Welfare Impact
}

\author{
Wa Hesty*, Firda Hidayati, Irwan Noor \\ Public Administration Science, Administration Science Faculty \\ Brawijaya University \\ Malang City, Indonesia \\ *wahesty@student.ub.ac.id, firda_fia@ub.ac.id,irwannoor@yahoo.com
}

\begin{abstract}
Food security becomes more fragile after a pandemic covid-19 hit the world. Strengthening Food Systems should become more prevalent to avoid food insecurity. This study proposed a combination of social and environmental welfare impact to the sustainable model of food systems that should enhance food security after a crisis. The method used is literature review. Data analysis is using information from previous research. The new model of food system has enlarged the food system activities including: production, processing and packaging, retailing and distribution and consumption. The sustainable food system model uses an approach of Twin Track with digital using based on people's behavior and conditions. Furthermore, the role of cooperation between stakeholders (government, private sector, and society) in all lines is the key to strengthening community food security. Their collaboration is needed to support the implementation of a model for a sustainable food system. The finding should enriched the knowledge of food security under complex and rapid changing of global pressure, especially Covid-19 pandemic.
\end{abstract}

Keywords-food security, sustainable food system, twin track approach

\section{INTRODUCTION}

Various efforts have been made by the government in tackling the spread of Covid-19. One of them is the LargeScale Social Restrictions policy (PSBB). PSBB policy is to restrict certain activities of residents in an area suspected of being infected with Covid-19 in such a way as to prevent the possible spread of Covid-19 [1]. This policy has negative implications for the welfare of society where the supply of food needs for the community is decreased [2,3]. The number of food-insecure villages has increased due to the implementation of large-scale social restrictions [4]. Furthermore, there has been an increase in technology-based people's purchasing power and an accumulation of foodstuffs as food reserves by the community $[3,5]$

The Covid-19 pandemic crisis has created a new era of order. Some precaution can be taken to adapt to the new era normal situation, especially in the field of food. There are four ways to act (CB) as a buffer for the program to increase food availability in the new normal era. The four ways are as follows [6]: 1) CB1 is an increase in production capacity; 2) $\mathrm{CB} 2$ is development of local food diversification based on local wisdom and utilization of homestead land through the sustainable food yard program (P2L); 3) CB3 is strengthening food reserves and logistics systems to stabilize food supply and prices; 4) CB4 is modern agricultural development. The strategy to strengthen food security is carried out through the development of a sustainable food system model, namely strengthening the production process to the consumption process using a socio-ecological approach [4,7-9].

Changes in people's behavior during a pandemic have resulted in changes to the adaptation of the food system model becoming more practical. The model innovation is the interaction of food system activities and their impacts through the Twin Track approach with digital technology using [10-12]. Synergy from stakeholders is needed to strengthen community food security. Collaboration between local governments and other stakeholders is the key to the successful implementation of a food security policy strategy $[12,13]$, . How to model a sustainable food system and who are the important stakeholders who take part in this model are the benchmarks and objectives in writing this article.

\section{THEORETICAL REVIEW}

\section{A. Concept of Twin Track Approach}

In accordance with the Instruction of the Minister of Home Affairs No.1 of 2020, local governments can ensure and monitor the adequacy of food in their respective regions both in terms of supply availability and smooth distribution. This policy was made so that the food needs of the community during the Covid-19 pandemic were still fulfilled in a sustainable manner so that the number of people with food insecurity could be prevented. The implementation of sustainable management of food security can be done through the food system activity with the Twin Track approach $[11,14,15]$. 


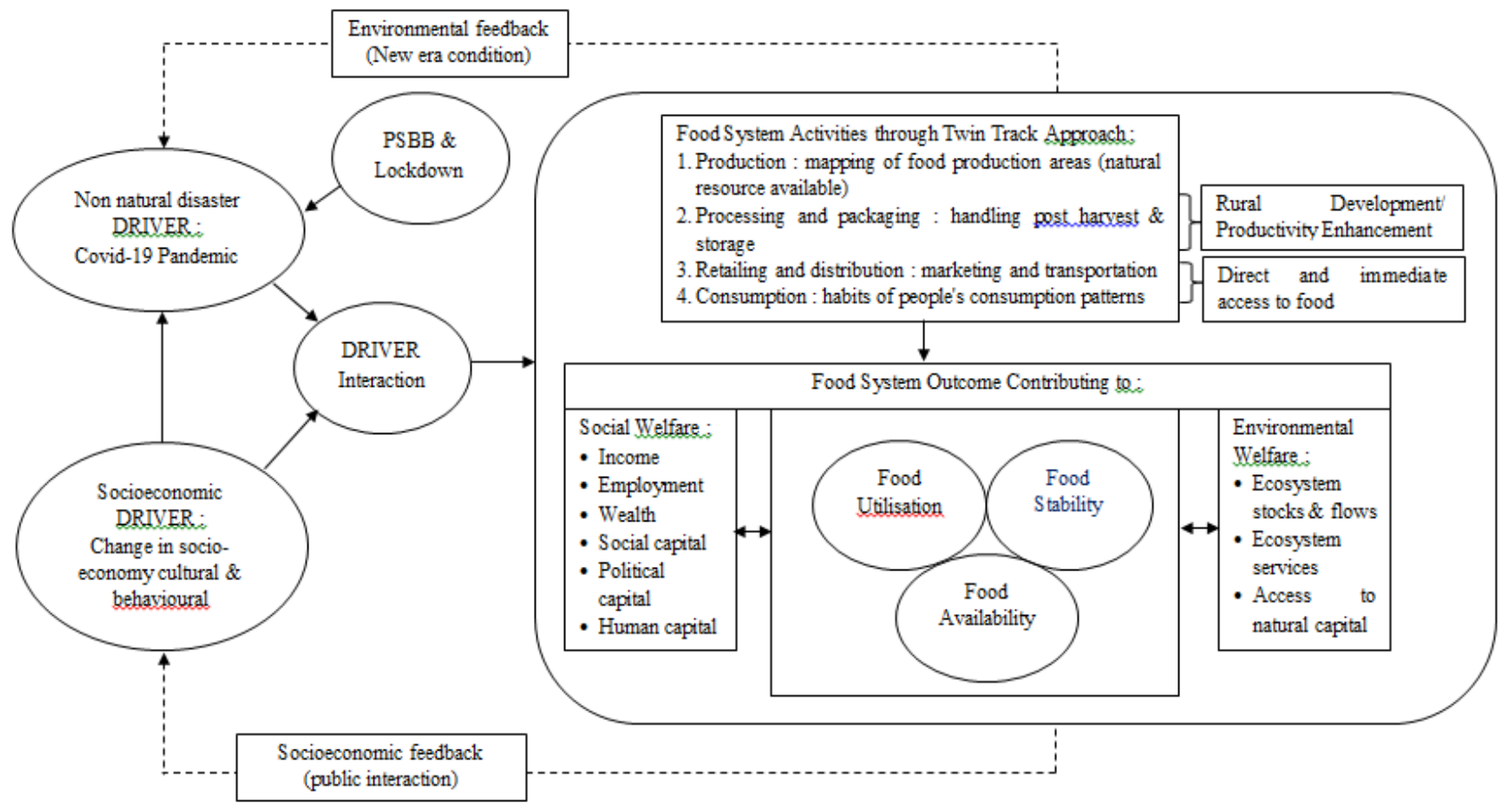

Fig. 1. Twin track approach and outcome [15].

The twin track approaches are a food system rehabilitation activity. These approaches include mitigation and adaptation to ensure future food security and are available as an interactive web tool to provide evidence for policymakers in long-term planning [11]. They are the food system activities and carried out in two stages, namely rural development/productivity enhancement and direct and immediate access to food. The difference between these lies in the goal. The first enhancement aims to increase productivity and added value from food, while the second enhancement transfers ownership from consumers to distributors/consumers. Undertaking these activities leads to a number of outcomes, which not only contribute to food security, but also relate to environmental and other social welfare issues. Food security outcomes are grouped into three components namely availability, stability, and utilization. Both the activities system and their outcomes are influenced by the interacting disaster and socioeconomic drivers and the environmental, food security and other social outcomes of the activities feedback to the drivers (Fig 1).

\section{B. The Food System Activities}

Activities in the food system are divided into four groups. Each has its own group of actors who govern each operation. Some actors (e.g. major supermarkets) span several activities [15]:

- Producing food involves all operations related to the processing of raw foodstuffs. Farmers, hunters, fishermen, various suppliers of production inputs, including agricultural goods, farm workers and landowners are key actors.
- Processing and Packaging Food includes the volume of material that the raw food content (e.g. grain, vegetables, fruit, animals) undergoes before it is sent for sale to the retail market. Main players include intermediaries that buy from suppliers and sell to processors; managers and employees in manufacturing and packaging plants; and industry associations that set standards.

- Retailing and distributing it involves a variety of intermediaries between suppliers, producers, packers and the final markets and the many players involved in, for example, transport, distribution, and warehousing, advertising, trade and supermarkets.

- Consuming It includes both consumers themselves and the various actors that concern what they working, such as market regulators, marketers, consumer groups, etc.

\section{The Food Security Outcomes and Their Elements}

\section{1) Food availability}

- Production = How much and what kinds of food are accessible through local production.

- Distribution = How food is made (physically transported) available, in what form, when and to whom.

- Exchange $=$ How much of the food available is acquired by exchange processes such as barter, swap, procurement, or loans. 


\section{2) Food stability}

- Affordability = the buying power of households or societies relative to food prices.

- Allocation $=$ the economic, social and political processes that regulate when, where and how consumers can access food.

- Preference $=$ Economic, religious or cultural values that affect the demand of consumers for certain kinds of food.

\section{3) Food utilization}

- Nutritional value $=$ How much of the daily calorie, vitamin, protein, and micronutrient needs are given by the food people eat.

- Social value $=$ the social, religious and cultural functions and benefits food provides.

- $\quad$ Food safety = Toxic contamination when food is grown, processed and packaged, shipped or marketed; and foodborne illnesses such as salmonella and CJDD.

\section{METHODOLOGY}

The method used in this research is literature review. Data analysis is using information from previous research on the problem of the impact of the spread of Covid-19 on the food system. The analysis is used to find alternative strategies for planning sustainable food security because of that. Stand-alone literature reviews can serve as valuable overviews of a topic for planning practitioners looking for evidence to guide their decisions, and therefore their quality can have very real-world implications. The planning field needs to increase its rigor in literature reviews [16].

\section{RESULTS AND DISCUSSION}

\section{A. Condition Food System in Covid-19 Pandemic}

In the midst of the current Covid-19 pandemic, all aspects of life tend to lead to new normal conditions. The policy of large-scale restrictions (PSBB) and regional quarantine (lockdown) has brought changes to new situations in almost all aspects of life, including changes in food system activities and results from production to consumption (upstream to downstream processes). The Covid-19 pandemic crisis has created a new era and consequences for food systems. Some of the significant changes and mitigation strategies in the food system caused by the Covid-19 pandemic are as follows:

1) Producing: From the production side, farmers and food producers feel changes in input supply and must also adjust production protocols to ensure food quality and safety in the midst of the Covid-19 pandemic, especially in polluted areas. At this level, the impact caused by Covid-19 and the adaptation of the food system mitigation model are as follows:

- Decreasing the availability of inputs for crop and livestock production : availability and timely delivery of agricultural inputs at affordable prices by improving the transportation system [3]

- Reduction of labor: movement of labor to laborintensive production areas resulting in labor-saving technology, and production facility assistance by the government $[5,17]$.

- Reduction of agricultural extension support development of information technology-based extension systems that focus on agricultural research and development activities [3].

Production is the main foundation in the food activity system so that production facilities, such as agricultural machinery and equipment, fertilizer and seed subsidies, and other production support facilities, are a priority for increasing production. Providing facilities and assistance to the community aims to improve production performance [4]. The food commodities produced can be in the form of agricultural, livestock and fishery products through community empowerment business activities. At this level, the government has a role as a policy maker and production facility assistance provider, the private sector as a third party in the procurement of goods/services, and the community as the target group for implementing empowerment programs.

2) Processing and packaging: Food commodities that have been harvested will be treated according to their characteristics. Grain will be dried beforehand before being ground and packed into sacks, eggs will be packed in cardboard racks, and fish will be chilled and packed in boxes. Post-harvest handling is carried out by observing health protocols. Farmers or producers will spray disinfectants on themselves and post-harvest tools used, use masks/face shields and gloves, and limit activities and labor. This results in inefficiency in post-harvest handling, thereby reducing productivity. The impact that occurs and the mitigation model at this level is as follows:

- Reduction/ cessation of production: ensuring the availability of raw materials and labor, proper postharvest handling $[18,19]$.

- Increase in the number of layoffs: subsidize companies to retain workers and provide severance pay in the form of tax exemptions by companies [3].

- Production and supply of less safe and poor quality products: increased storage capacity and better distribution $[18,20]$.

- Less capital required: encourages diversification of products and markets [4].

- Psychological implications: implementing quality consultation and monitoring [3].

At this level, producers, namely the public and the private sector who run businesses to produce good quality products, have a very important role. The government as the formulator 
of policies, especially in terms of controlling the safety of the products produced.

3) Retailing and distribution: Food mobilization will also undergo several adjustments where there is a pattern of changing supply lines towards a modern market and an onlinebased market. At this level, the impacts and mitigation adaptations that can be carried out are as follows:

- Food scarcity in urban areas and rising food prices: strengthening domestic food reserves and supply chains (logistic system) [21-23].

- Fewer business actors: support and strengthen business actors as suppliers in order to function properly [3].

- Marketing system slowdown: adopting a new digitalbased marketing system and collaborating with the private sector in delivery services $[10,12]$.

- Reduced supply and demand for several types of foodstuffs due to information asymmetry and loss of paper currency: increasing access to food by vulnerable people through cash for work schemes and strengthening the role of the transportation system [20].

This level is a critical level as a determinant of community food security. Therefore, the government (policy makers), the private sector (suppliers), and the public (food accessors) must work together because they are related to one another. Transactions occur between buyers (people) and sellers (distributors) digitally with a delivery intermediary (delivery). This was done to minimize the spread of the Covid-19 pandemic.

4) Consuming: At this level, some changes in consumption behavior and the ways of adapting to these changes are as follows:

- Increase in consumption of healthy food: utilization of food must be improved by taking into account information on food safety [24].

- Reduction in purchasing power of food in cafes / restaurants: culinary entrepreneurs diversify their services by utilizing digital technology [10].

- Increase in food prices: the government controls prices by strengthening food reserves and the logistics system [3].
To support the increase in people's purchasing and consuming power, the government provides fiscal stimulus and foodstuffs in the form of assistance, especially for low-income people who are affected by layoffs. At this level, the government remains as a policy maker (security and control of food prices), the private sector (providers of products and services), and the public (consumers /customers)

\section{B. Alternative Strategies for Sustainable Food System Model}

In general, the sustainable food system model changes according to the behavior and conditions of society. With these changes, the government is required to make strategic adjustments to policies related to food at all levels (production to consumption) so that food security in Indonesia is guaranteed. According to the "stakeholder value" belonging to the new ecosystem, both large and small enterprises in the space sector (space agencies, governments, etc.) and SMEs from non-space sectors (i.e., start-ups and incubators) have to be involved in the changing process [12]

Taking into account Indonesia's geographical conditions, the distribution of its population, and the increasingly inelastic demand for food in the midst of the COVID-19 pandemic, it is important if the supply chain can be optimized and a logistic system can be implemented properly. It is because the logistics and supply chain sector is the key sector that can maintain the food security outcome namely availability and stability of Indonesian food prices. Supply chain and logistics capability are a key dimension of strengthening and further efforts to strengthen food security $[2,23,25]$.

The government needs to encourage and facilitate the logistics sector to run optimally, especially in terms of providing infrastructure and other special facilities. In addition, the relationship between stakeholders is a priority so that food distribution, food availability, and food price stability are maintained. Local governments can work with food security councils to formulate food security policies [13]. If there is no stakeholder role and clear policy support, then strengthening food security will not occur. The host of governmental and non-profit relief approaches have been implemented before and during the Covid-19 pandemic to help alleviate food insecurity, these strategies have served as temporary "band-aids" [10] 


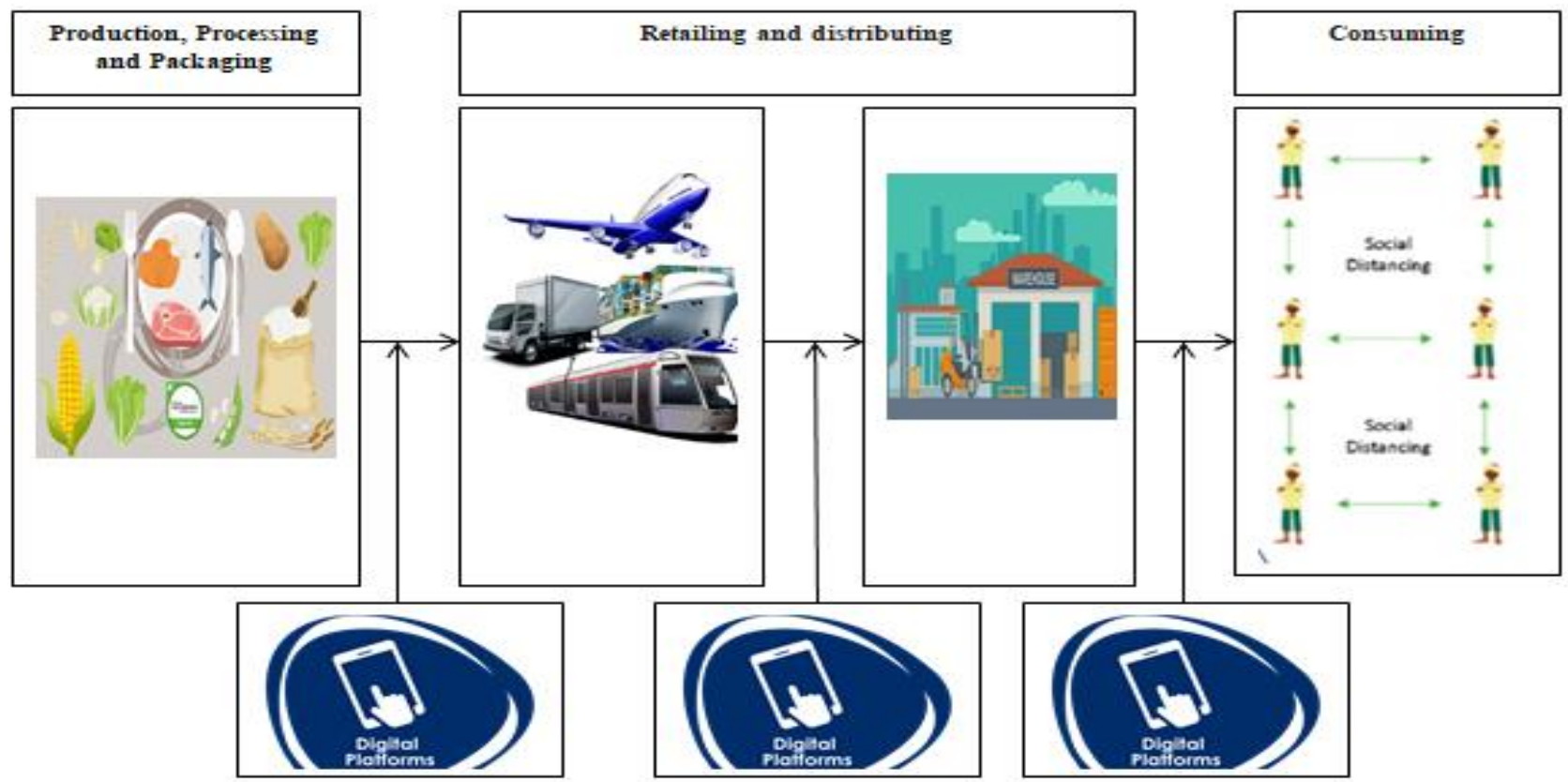

Fig. 2. Model sustainable food systems framework.

During the Covid-19 pandemic, the local government in Indonesia took measures to strengthen the sustainable food security of the society. The sustainable food security model aims to meet the current and future needs of society (figure 2). The sustainable food system model is carried out by the community starting from the production process to consumption by utilizing digital technology and implementing health protocols. That model uses the Twin Track approach with a digital transaction that focuses on activities to improve agriculture and access to food. The use of digital technology is an alternative in making faster transactions. It can help increase effectiveness and efficiency in strengthening food security. Innovations in the food system directly assist the development of the agricultural sector [26]. It aims to fulfil the people's food needs so contribute directly to improving socioeconomic and environmental welfare.

\section{CONCLUSION}

The model of a sustainable food system changes according to people's behavior and conditions by utilizing digital technology. It has been developed to maintain food security in the community from producing to consuming. Digital technology in the food system is a new alternative for fast transactions so that food security activities become more effective and efficient. In addition, society can easily distribute, access and consume food with digital technology. Therefore, there needs to be infrastructure support and good socialization from the local government so that a sustainable food system model can exist so that food security in the community is maintained in the future. It is because partly rural communities have not been able to master technology well and the lack of quality of ASN public services.

\section{REFERENCES}

[1] Presiden Republik Indonesia, Peraturan Pemerintah Nomor 21 Tahun 2020 tentang Pembatasan Sosial Berskala Besar Dalam Rangka Percepatan Penanganan Coronavirus Disease 2019/COVID-19, vol. 2019. Indonesia: Jaringan Dokumentasi Informasi Hukum Sekretariat Kabinet Republik Indonesia, 2020, pp. 1-8.

[2] J. E. Hobbs, "Food supply chains during the COVID-19 pandemic," Can. J. Agric. Econ. Can. d'agroeconomie, vol. 68, no. 2, pp. 171-176, Jun. 2020.

[3] S. A. Omer and N. A. Hassen, "Impacts COVID-19 pandemic Diseases on Ethiopian Agriculture, Food Systems, Industries, and Mitigation and Adaptation Strategy," Electron. J. Educ. Soc. Econ. Technol., vol. 1, no. 1, pp. 18-33, 2020.

[4] R. Masniadi, M. A. Z. Angkasa, E. Karmeli, and S. Esabella, "Telaah Kritis Ketahanan Pangan Kabupaten Sumbawa dalam Menghadapi Pandemi COVID-19," Indones. J. Soc. Sci. Humanit., vol. 1, no. 2, pp. 109-120, 2020.

[5] S. Devereux, C. Béné, and J. Hoddinott, "Conceptualising COVID-19's impacts on household food security," Food Secur., vol. 12, no. 4, pp. 769-772, Aug. 2020.

[6] Biro Komunikasi Institut Pertanian Bogor, "Strategi Ketahanan Pangan di Era New Normal Pandemi COVID-19," Bogor: Biro Komunikasi Institut Pertanian Bogor, 2020.

[7] A. Paloviita, T. Kortetmäki, A. Puupponen, and T. Silvasti, "Vulnerability matrix of the food system: Operationalizing vulnerability and addressing food security," J. Clean. Prod., vol. 135, pp. 1242-1255, Nov. 2016.

[8] A. Cavallo, B. Di Donato, and D. Marino, "Mapping and Assessing Urban Agriculture in Rome," Agric. Agric. Sci. Procedia, vol. 8, pp. 774-783, 2016.

[9] J. M. Bullock., "Resilience and food security: rethinking an ecological concept," J. Ecol., vol. 105, no. 4, pp. 880-884, 2017.

[10] M. I. Huizar, R. Arena, and D. R. Laddu, "The global food syndemic: The impact of food insecurity, Malnutrition and obesity on the 
healthspan amid the COVID-19 pandemic," Prog. Cardiovasc. Dis., no. January, pp. 19-22, Jul. 2020.

[11] K. J. Richardson, K. H. Lewis, P. K. Krishnamurthy, C. Kent, A. J. Wiltshire, and H. M. Hanlon, "Food security outcomes under a changing climate: impacts of mitigation and adaptation on vulnerability to food insecurity," Clim. Change, vol. 147, no. 1-2, pp. 327-341, 2018.

[12] A. Di Vaio, F. Boccia, L. Landriani, and R. Palladino, "Artificial Intelligence in the Agri-Food System: Rethinking Sustainable Business Models in the COVID-19 Scenario," Sustainability, vol. 12, no. 4851, pp. 1-12, 2020.

[13] C. Gupta, "Food Policy Councils and Local Governments: Creating Effective Collaboration for Food Systems Change," J. Agric. Food Syst. Community Dev., vol. 8, no. October, pp. 11-28, Oct. 2018.

[14] P. Pingali, L. Alinovi, and J. Sutton, "Food Security in Complex Emergencies: Enhancing Food System Resilience,” Disasters, vol. 29, no. SUPPL., pp. S5-S24, Jun. 2005.

[15] J. Ingram, "A food systems approach to researching food security and its interactions with global environmental change," pp. 417-431, 2011.

[16] Y. Xiao and M. Watson, "Guidance on Conducting a Systematic Literature Review,” J. Plan. Educ. Res., vol. 39, no. 1, pp. 93-112, Mar. 2019.

[17] S. Devereux, "Social protection for enhanced food security in subSaharan Africa," J. FOOD POLICY, 2015

[18] A. G. Mezgebe, Z. K. Terefe, T. Bosha, T. D. Muchie, and Y. Teklegiorgis, "Post-harvest losses and handling practices of durable and perishable crops produced in relation with food security of households in Ethiopia: secondary data analysis," J. Stored Prod. Postharvest Res., vol. 7, no. 5, pp. 45-52, 2016.
[19] M. J. Chegere, "Post-harvest losses reduction by small-scale maize farmers: The role of handling practices," Food Policy, vol. 77, no. May, pp. 103-115, May 2018.

[20] B. Gbam, "Effect of Transportation on the Marketing of Agricultural Products in Jos North," J. Res. Bus. Manag., vol. 5, no. 2, pp. 99-106, 2017.

[21] M. Rozikin, "The Usage Urgency of Information Technology toward the Distribution Management of Disaster Relief Logistics for Mountain Eruption Evacuees with Disaster Relief Operations (DROs) Approach," vol. 93, no. 24, pp. 280-284, 2019.

[22] M. Jamaludin, T. H. Fauzi, D. Novan, S. Nugraha, and L. Adnani, "Service Supply Chain Management in the Performance of National Logistics Agency in National Food Security," vol. 9, no. 3, pp. 10801084, 2020.

[23] S. Singh, R. Kumar, R. Panchal, and M. K. Tiwari, "Impact of COVID19 on logistics systems and disruptions in food supply chain," Int. J. Prod. Res., vol. 0, no. 0, pp. 1-16, Jul. 2020.

[24] C. Huet, J. D. Ford, V. L. Edge, J. Shirley, N. King, and S. L. Harper, "Food insecurity and food consumption by season in households with children in an Arctic city: a cross-sectional study," BMC Public Health, vol. 17, no. 1, p. 578, Dec. 2017.

[25] C. M. Galanakis, "The Food Systems in the Era of the Coronavirus (COVID-19) Pandemic Crisis," Foods, vol. 9, no. 4, p. 523, Apr. 2020.

[26] L. Klerkx, E. Jakku, and P. Labarthe, "A review of social science on digital agriculture, smart farming and agriculture 4.0: New contributions and a future research agenda," NJAS - Wageningen J. Life Sci., vol. 9091, no. November, p. 100315, 2019. 